\title{
Weapons of the Powerful: \\ Authoritarian Elite Competition and Politicized Anticorruption in China
}

\section{By Jiangnan Zhu and Dong Zhang \\ (A further revised final version of this article is accepted by Comparative Political Studies)}

\begin{abstract}
What motivates authoritarian regimes to crack down on corruption? We argue that just as partisan competition in democracies tends to politicize corruption, authoritarian leaders may exploit anticorruption campaigns to target rival supporters during internal power struggles for consolidating their power base. We apply this theoretical framework to provincial leadership turnover in China and test it using an anticorruption data set. We find that intraelite power competition, captured by the informal power configuration of government incumbents and their predecessors, can increase investigations of corrupt senior officials by up to $20 \%$. The intensity of anticorruption propaganda exhibits a similar pattern. The findings indicate that informal politics can propel strong anticorruption drives in countries without democratically-accountable institutions, although the drives tend to be selective, arbitrary, and factionally biased.
\end{abstract}




\section{Introduction}

Corruption, defined as the abuse of public office for private gain (Nye, 1967), undermines the economy and regime legitimacy (Seligson, 2002). High-quality institutions for political and economic competitiveness (Treisman, 2007), such as liberal democracies (Montinola \& Jackman, 2002; Rose-Ackerman, 1999), media supervision (Brunetti \& Weder, 2003), and market competition (Ades \& Di Tella, 1999; Aidt, 2009; Sandholtz \& Koetzle, 2000), are often credited with reinforcing state officials' incentives to combat corruption. By contrast, nondemocratic countries without accountable institutions are expected to be weak in corruption control. Nevertheless, rather than a perennially condoning attitude, authoritarian governments may periodically wage wars on corruption. For instance, Rwanda and South Korea strengthened anticorruption institutions and experienced reduced corruption when becoming more autocratic (Hollyer \& Wantchekon, 2015). Indonesia launched several attempts to eradicate corruption under Suharto's regime (Quah, 1999). China is another notable authoritarian country with periodic anticorruption campaigns featuring intense investigations against corrupt officials (Manion, 2004; Wedeman, 2005). Therefore, the questions are, why and when do authoritarian regimes strike harder at corruption? What mechanisms drive the dynamics of anticorruption activity in countries with weak or absent democratic and institutional accountability?

Without institutional guarantees to curb corruption, temporary anticorruption campaigns in authoritarian states may be a political response to stimuli external to the ruling clique such as extreme public dissatisfaction with corrupt officials, a decline of social control instruments (e.g., ideological indoctrination), and political developments in other countries (Gillespie \& Okruhlik, 1991; Hollyer \& Wantchekon, 2015). A prerequisite for these stimuli is a benevolent incumbent concerned with public support and the long-term survival of the regime (Chang \& Golden, 2010; Rose, Mishler, \& Munro, 2011). However, a popular revolt remains a secondary concern for 
rulers, whose primary concern is managing relations with the ruling allies (Svolik, 2012). While condoning corruption enables authoritarian leaders to buy loyalty from their inner circles (Bueno de Mesquite et al., 2003), anticorruption campaigns can also be used to purge political rivals.

We contend that the intensity of intraelite power competition is a major force within the ruling clique driving the anticorruption dynamics in authoritarian states. When political competition is intense, leaders tend to pursue anticorruption campaigns to eliminate their rivals. By contrast, leaders tend to tolerate corruption when competition is less intense. This cycle is similar to the politicization of corruption in democracies, where it is used to discredit opponents during elections. While such politicization mainly occurs between political parties in democracies, informal power networks and coalitions are often the primary targets of anticorruption drives in authoritarian regimes. Leaders investigate corruption in their competitors' networks to weaken their rivals and thereby consolidate their hold on power. We conceptualize this logic as the politicization of anticorruption in authoritarian regimes.

In the subnational politics of leadership turnovers in China, former leaders of a jurisdiction may continue to influence local politics through their personal networks in the government because of the prevalence of informal politics (Huang, 2000). This political legacy can hinder the incumbents' power consolidation and political advancement. In response, the incumbents may investigate previous incidents of corruption to uproot predecessors' networks. We hypothesize that anticorruption activity tends to be the most intense when power transitions occur between leaders who are clients of strong patrons competing in the party center. With the patronage of senior party leaders, local incumbents have the greatest incentive and capacity to politicize anticorruption for weakening the local political networks of their powerful predecessors. By contrast, in other types of leadership turnovers, power conflicts between 
predecessors and incumbents are less intense and anticorruption investigations are fewer because either the incumbents cannot launch effective anticorruption drives against the preexisting political networks or they tolerate the corruption to gain support.

We test our hypothesis by examining the variation of anticorruption endeavors among Chinese provincial governments. We use the number of officials at and above the county/division levels (xian chu ji) investigated annually by the provincial procuratorates between 1996 and 2012 as a proxy for the provincial governments' anticorruption intensity. Large numbers are considered strong attacks on corruption. We code provincial officials' factional ties to identify the types of power transition at the provincial level. Using fixed effect models, we focus on variations within provinces and estimate the effects of different power transition types on anticorruption endeavors while controlling for a rich set of provincial and leaders' personal characteristics. We find that power transitions between leaders supported by strong patrons competing in the party center increase the number of officials investigated annually for corruption by $13-17$ (15\%-20\% relative to the mean). Moreover, we find similar patterns in government anticorruption propaganda, measured using the number of anticorruption articles in local party newspapers, further lending credence to our theoretical arguments.

Our research advances existing literature in several directions. First, while the extant scholarship is preoccupied with understanding the causes of corruption and the role of formal institutions in curbing corruption, our study investigates the influence of informal political networks and politicians' concerns with political survival on anticorruption endeavors in authoritarian regimes. Second, current literature on authoritarianism emphasizes the role of elite unity and power-sharing in sustaining authoritarianism (Brownlee, 2007; Gandhi, 2008; Magaloni, 2008; Svolik, 2012), whereas our findings suggest that elite cleavage may potentially 
deter unbridled corruption. Finally, in addition to socioeconomic achievements in interjurisdictional competition (Guo, 2009; Lu \& Landry, 2014) and political connections to the top leadership (Shih, Adolph, \& Liu, 2012), we contend that the ability to dismantle rival power networks and consolidate the ruling coalition contributes to the career advancement of Chinese political leaders.

\section{Elite Power Competition and Politicizing Anticorruption in One-Party Regimes}

While political competition in electoral democracies discourages officials from engaging in corruption, intense competition among multiple parties can encourage politicization of corruption to win votes. In Europe, political parties during parliamentary elections have increasingly accused their opponents of being corrupt, because the narrowing ideological gap between political parties renders them increasingly indistinguishable to voters (Bågenholm, 2010). In the United States, politically appointed attorneys in the Department of Justice may have a partisan bias when prosecuting corruption cases. Public officials from Democratic localities were reported to be disproportionately targeted under Reagan, Nixon, and Ford (Gordon, 2009; Meier \& Holbrook, 1992). Politicians accused for corruption, regardless proven or merely alleged, can lose an election or career prospects (Peters \& Welch, 1980; Welch \& Hibbing, 1997). Power competition among authoritarian political elites can also stimulate politicization of anticorruption investigations.

Although genuine elections are absent in authoritarian regimes, leaders still compete over political positions and privileges at the national and local levels. Authoritarian leaders inherently rely on the loyalty of a group of allies (Tullock, 1987). Competing elites often have a coterie of second-rank leaders as supporters, leading to factions or vertical divisions within the collective leadership (Taras, 1989). Consequently, in centralized regimes, such as one-party dictatorships, 
factions substitute parties. Factional infighting functions as political competition for both senior elites and lower-level officials in the party (Ionescu \& de Madariaga, 1968). For example, in Mexico’s Institutional Revolutionary Party-dominated political system, party factionalism was characterized by "protracted leadership competition” with "major rounds of bargaining” (Ezrow \& Frantz, 2011, p. 199). In communist states, without institutional guarantees of power transition, previously designated successors may be marginalized by competing factions (Taras, 1989).

Thus, in authoritarian regimes, particularly one-party regimes, political success lies in the strength of coalitions or networks of loyal supporters, which are as vital to authoritarian leaders as votes are to political candidates in democracies (Bueno de Mesquite et al., 2003). Nationally, a looming opposition coalition can threaten authoritarian leaders' rule. Regionally, any power network disloyal to local administrators may become a liability in their policy implementation and political advancement, especially when the network is associated with their political rivals.

When competition intensifies, authoritarian leaders could terrorize or eliminate opponents “through murder, show trials, torture, and purges” (Haber, 2006, p. 698), such as Stalin’s purges of the Soviet Communist Party and the Red Army, and Saddam Hussein's purges of Iraq's Arab Socialist Ba'ath Party. However, deploying such terror entails extremely high stakes, because the leaders risk being eliminated by their rivals if they fail to attain the upper hand, and such terror may foment distrust and indiscriminate violence, undermining the functionality of the government (Haber, 2006; Tullock, 1987). To mitigate the dangers of elite competition, many authoritarian regimes have embraced adaptive institutions, such as elections and open legislative contestations (Magaloni, 2006; Gandhi \& Przeworski 2007; Levitsky \& Way 2010; Malesky \& Schuler 2010). Political elites (and lower-level officials) obtain an institutional venue to compete for power, patronage, and distribution of state resources (Lust-Okar, 2006). Party institutions in 
one-party regimes also facilitate power sharing between the dictator and ruling coalition by forming credible and intertemporal power-sharing deals with potential opponents (Magaloni, 2008; Svolik, 2012). Thus, such adaptive institutions enable authoritarian leaders to manage the expectations of elites, reconcile competition, and deter defection.

With institutional adaptation, politicization of corruption becomes one of the viable means for weakening rivals. Fighting corruption facilitates legitimizing the regime's seizure of power and establishing a complete system of support from different factions by intimidating contending elites with legal pretexts (Heidenheimer \& Johnston 2009). Corruption cleanups may occasionally develop into high-level purges of the ruling party, usually shortly after revolutions and coups, when authoritarian leaders are eager to delegitimize the preceding regime and win public support (Gillespie \& Okruhlik 1991). However, after adaptive institutions are established, resorting to large-scale purging undermines the credibility of the power-sharing deal and forces ruling elites to the opposition coalition. Thus, upholding "the power-sharing arrangement with his ruling clique to make his life less vulnerable” (Magaloni, 2008, p. 10) is in a dictator's interest. When launching anticorruption campaigns, authoritarian rulers are cautious to restrain them from escalating into indiscriminate purges.

To avoid acknowledging widespread corruption and discrediting the entire regime, authoritarian leaders tend to target major political opponents and selectively investigate scandals of clearly identified wrongdoers (Gillespie \& Okruhlik, 1991). In contrast with democracies, which have open contestation among multiple parties, single-party authoritarian regimes do not openly tolerate the emergence of intraparty conflicts; they "hide any appearance of internal splits from the public eye so as to project an aura of party invulnerability” (Ezrow \& Frantz, 2011, p. 199). In addition, competing politicians are discouraged from defecting from the party because 
an elite split may result in the loss of power over the regime (Geddes, 2003). Therefore, unlike democracies, politicization of anticorruption often does not directly target a dictator's competitor; instead, it targets the competitor's network of supporters, usually mid- to low-level officials, because they are a more vulnerable and safer target with regard to regime stability. In addition, because the ultimate objective is to remain in power, when competition is less intense, authoritarian political elites may tolerate corruption to co-opt potential challengers.

Therefore, the primary force politicizing anticorruption in one-party authoritarian regimes is the intensity of power competition among ruling elites. With the ultimate goal of remaining in power through the ruling party, political elites tend to employ this strategy against their major rivals, and they target supporters who form the political networks of competing political elites in the ruling party.

\section{Anticorruption amid Intraelite Competition in China}

Since the economic reforms, corruption in China has grown tremendously with increasing sophistication and involvement of larger funds and high-level officials (Gong, 1997; Guo, 2008; Wedeman, 2004), and the state has arduously fought this problem. The Central Discipline Inspection Committee (CDIC) and its local Discipline Inspection Committees (DICs) in the party are the primary anticorruption organizations, supplemented by the Ministry of Supervision and the procuratorate. The DICs enforce party disciplines, monitor and punish corruption and various wrongdoings of party members (Guo, 2014). They are the first to investigate a case and decide whether to refer it to the procuratorate for further investigation. The state has implemented routine anticorruption measures, such as audits of the government official departures and performance reviews of the disciplinary departments. Furthermore, the party center combines regular "police patrols" with campaign-style enforcement to temporarily crackdown on 
corruption, resulting in short-term increases in investigations and prosecutions for corruption (Wedeman, 2005).

Nonetheless, the intensity of anticorruption investigations at the local level is largely influenced by the party leaders at various administrative levels. Theoretically, local DICs can supervise any official under their authority. However, they are subject to the leadership of local party committees, which substantially control DIC officials' salaries, benefits, and promotions. Within the party committees, party secretaries are usually the most influential. Moreover, the heavily politicized judicial system facilitates party leaders’ control over the court (Pei, 2006). If local party secretaries choose to tolerate corruption in their jurisdiction, corrupt officials may circumvent DIC investigations and legal ramifications (Guo, 2014). During the short bursts of aggressive enforcement, local party secretaries have even more latitude in deciding the timing, intensity, and targets of investigations. Thus, local party secretaries often possess the fundamental decision-making power to condone or condemn corruption among their subordinates (Manion, 2004). Although the CDIC has strengthened the vertical leadership over its local branches since 2004, it is almost impossible for the central and local DICs to independently investigate a case without the support of the powerful local party leaders. In addition, the CDIC has approximately 2,000 employees distributed over 27 internal departments, among which only 10 offices specialize in discipline inspection and supervision (Guo, 2014). Every month, the CDIC receives thousands of corruption reports including personal visits, letters, phone calls, and online reports ${ }^{1}$; it is thus understaffed and can primarily focus only on cases involving high-level officials, leaving anticorruption efforts targeting leaders at and below the prefectural level to the local DICs. Therefore, local party secretaries’ preferences and incentives 
in combating corruption substantially affect local anticorruption endeavors. Their leadership over anticorruption activities further affords them opportunities to politicize anticorruption.

Similar to other one-party regimes, the Chinese Communist Party (CCP) has a long history of infighting among party leaders. Pursuing career security and advancement, many political elites form informal groups on the basis of personal ties (Nathan, 1973; Pye, 1981). Factions constantly jockey for dominance within the party, especially during national and local leadership transitions. The dominant factional networks may launch large-scale campaigns to consolidate power at the expense of the dominated networks (Huang, 2000). Historically, intense factional infighting led to irrational purges and vicious struggles for succession until the late 1980s. Recent emphasis on procedural rules, such as norm-bound succession politics and term and age limits for retirement, has restrained factional competition from deteriorating into endless power struggles and has reinforced within the leadership the feeling that removal should arise from just causes (Li, 2012a; Nathan, 2003; Teiwes, 1984). Thus, corruption investigations have become a widely adopted means, among others, for resolving intraelite competition because such investigations require evidence and follow relatively public legal proceedings to eliminate officials, while appealing to public demand for a clean government.

During anticorruption campaigns, factions play a role similar to that of political parties in democracies in differentiating politicians' political competitiveness and power affiliations. Competitive officials are often affiliated with strong factions led by powerful patrons, such as Long Marchers and members of the Standing Committee of the Politburo (PSC) in the central government. For example, in the early reform years, Deng Xiaoping and his followers were a dominant force, but they occasionally faced strong opposition from conservatives, led by other party elders such as Chen Yun (Shih, 2008a). From the mid to late 1990s, officials networked 
around Party Secretary General Jiang Zemin, Premier Li Peng, and Chairman of the National People’s Congress Qiao Shi, all of whom competed for party dominance (Fewsmith, 2001). Since the late 1990s, the "elitist coalition" and the "populist coalition" have risen. The elitist coalition is loosely constituted by princelings-leaders whose parents are either veteran revolutionaries or high-ranking officials—and the Shanghai Gang—Jiang Zemin’s protégés in Shanghai. The populist coalition was led by former president Hu Jintao and a core group of the so-called Tuanpai-leaders who advanced their political career primarily through working in the Chinese Communist Youth League (CCYL) (Li, 2013). Many members of these two coalitions became key provincial leaders and members of the PSC and Politburo. However, not all officials participated in factional competition and some were merely members of local power groups. Without a powerful central patron for essential support, these officials can be considered factionless or belonging to weak factions. Official appointments during leadership turnovers often result from complex bargaining, trading, and compromising processes between different factions and central leaders ( $\mathrm{Li}, 2012 \mathrm{~b}) .{ }^{2}$ Power transitions between the outgoing provincial party secretaries and their successors can be generally categorized into five types according to the leaders' factional affiliations (Figure 1).

\section{[Figure 1 about here]}

We argue that the tendency to politicize anticorruption is the strongest in Type I (strong/strong-contender) power transitions. Because of factionalism, relinquishing a position, irrespective of the reason (rotation, retirement, or even subversion), does not necessarily imply that the leader's local influence has evaporated. As long as the leader's factional networks persist, he or she may have a substantial influence on local affairs (Huang, 2000). Predecessors from strong factions may have more opportunities for promotion to positions that are more 
authoritative, and their powerful patrons in the central government may lend them more political capital to maintain wide networks. These advantages can prompt the predecessors' local followers to remain loyal even after the predecessors relinquish their positions. ${ }^{3}$

However, loyalty to a predecessor is often a threat to an incumbent from another faction. The patron-client network inherently suffers from the commitment problem. If followers want to continue receiving benefits from their patrons, such as promotions and subsidies, they must gain their patrons' trust by credibly demonstrating loyalty such as by constantly rendering payoffs (e.g., profitable projects) to their patrons and through public displays of obsequiousness (Shih, 2008b). However, local officials loyal to the predecessor may be less cooperative with the incumbent. Local officials who are under the protection of the powerful predecessor and involved in collective corruption through a network of departments, businesspeople, and even organized crime groups (Gong, 2002) are particularly self-protective and unwilling to share local tribute with a new leader. The new leader thus faces obstacles in building his or her own local power coalition and implementing an agenda that appeals to his or her patrons. Thus, new provincial secretaries, similar to partisan prosecutors in democracies, may be motivated by factional biases when investigating corruption cases that occurred under their predecessors. The secretaries can subsequently replace the purged local officials with their loyalists to strengthen their power base. Moreover, in Type I power transitions, the predecessor and incumbent are more likely to be in competition, because clients of powerful central patrons tend to be promising political stars (Shih et al., 2012). Arresting corrupt officials promoted by predecessors might reflect predecessors' problem in managing local cadres and offer the incumbents' central patron a pretext for blocking further promoting the predecessors. 
A prominent example involves Wang Yang, a well-known member of the CCYL faction, and Bo Xilai, a member of the princeling class. After Wang Yang's promotion as the party secretary of Guangdong Province in 2007, Bo Xilai (son of Bo Yibo, a revolutionary belonging to Deng Xiaoping's inner circle in the 1980s) succeeded Wang as the party secretary of Chongqing. ${ }^{4}$ Both Wang and Bo were widely considered major contenders for seats in the PSC during the 18th Party Congress. Bo's campaign against organized crime and corruption in Chongqing was widely suspected of being a political move to cripple his predecessors' local network and discredit Wang, who he deemed his major rival (Fewsmith, 2010; Wedeman, 2012).

In the aforementioned scenarios, predecessors may step out to protect their former followers. However, such protection can be costly, often requiring exchange for withdrawing power competition or arousing suspicion of corruption of the protectors. ${ }^{5}$ Thus, protection presumably is stingily offered only to those extremely crucial followers of the predecessors. Type I power transitions in general substantially motivate politicization of anticorruption and precipitate the prosecution of local corruption cases, leading to irregular peaks in anticorruption enforcement. Such motivations are much weaker in other transition types. When the predecessor and the incumbent belong to the same faction (Type II), to guard factional interests and avoid arousing suspicions against their shared patron, the incumbent has less motivation to uncover corruption under his or her predecessor. In Type IV power transitions, when the predecessor belongs to no faction or a weak faction and the incumbent is from a strong faction, the incumbent has a weaker need to undermine existing local power networks through corruption prosecution. Local officials who receive little protection from their former leaders are easily to be co-opted by powerful incumbents to obtain benefits and avoid trouble. Even if the predecessor is entrenched in the locality, for example, provincial officials who rise from the grassroots to the provincial 
government through decades of promotions, bargaining for certain deals between the incumbent and the predecessor's loyalists is still relatively easy. The incumbent can govern without strong opposition from the preexisting local network as long as the loyalists lack a central patron. As Shirk (1993) observed, when officials are aware that their superiors can at will charge them with corruption, the lack of charges effectively becomes a benefit for which the officials gratefully exchange their political support. Thus, tolerating local corruption may help the incumbent win more local allies. In Type III and V power transitions, incumbents from weak factions may lack the capacity to pursue corrupt officials affiliated with extensive local networks.

In general, elite power competition can lead to politicization of anticorruption in China as in electoral democracies. We hypothesize that this tendency is the strongest during power transitions between politicians from different strong factions competing for party dominance and weaker in other types of power transitions. Therefore, selective toleration and prosecution of corruption is substantially influenced by the enduring intraelite infighting in China. This framework explains the temporal ebb and flow of anticorruption campaigns within a locality.

\section{Empirical Strategy}

\section{Data and Variables}

To measure the dependent variable-local governments' anticorruption efforts—we use the number of officials at and above county/division levels in China investigated by the provincial procuratorates between 1996 and $2012 .{ }^{6}$ Figures 2A and 2B illustrate the fluctuation in the number of investigated officials in all 31 provincial units during the aforementioned period. Although the fluctuations may stem from changes in both actual corruption and anticorruption efforts, there are several reasons to consider that the variations largely reflect fluctuations in local anticorruption efforts. First, party leaders usually interpret increased enforcement figures as 
political achievements and stronger commitment to anticorruption (Manion, 2004). In addition, scholars have identified in China a long time lag from the year officials were first involved in corruption to the year that they were found to be corrupt. On average, this crime-capture lag ranges from five to eight years since the 1990s (Guo, 2008). Therefore, what the anticorruption campaigns revealed are predominantly corrupt acts committed by officials several years ago. Given the rampant corruption in China, most provinces would likely have accumulated high levels of hidden corruption (Wedeman 2012). Moreover, corruption in China is broadly defined, including cases involving illicit monies as low as RMB5000 and moral misconduct such as dishonesty and adultery (Ko and Wong 2012). This conceptual ambiguity offers sufficient room to charge an official for being corrupt. Therefore, even a marginal and temporary decrease (or increase) in corruption might not fundamentally inhibit (or facilitate) the ability of local anticorruption agencies to investigate scores of officials from a large pool of corrupt officials when they launch an anticorruption campaign. However, we are aware that the aforementioned justifications require some strong assumptions. In the empirical tests, we relax the assumption on the level of corruption and carefully control for proxies of actual corruption and direct measures of corruption to eliminate fluctuations caused by changes in corruption, as elaborated subsequently.

\section{[Figure 2 about here]}

Our key independent variable is a dummy variable characterizing the type of power transitions. We first identify factional ties of the provincial party secretaries in our data set. Shih et al. (2012) provided a political biographical data set of Central Committee members from the first party congress in 1921 to the sixteenth party congress in 2002. This data set records not only leaders' demographic information of birth year, gender, year of induction into the party, 
education, ethnicity, and princeling status, but also every state, party, and military position held by them throughout their careers. We extend the data of provincial secretaries in this data set to 2012. In the seminal research on Chinese bureaucracy, Lieberthal and Oksenberg (1988) reported that bonds of guanxi arise among officials having family connections, common geographical origins, shared education, work, or military experience. Based on this finding, Shih et al. (2012) assumed that factional ties occur between officials and top leaders who share birthplaces, educational institutions, and work units. We follow this approach to code factional ties between provincial secretaries and powerful patrons in the party center. ${ }^{7}$ Leaders having ties with serving or retired PSC members are considered members of strong factions. Each princeling is also treated as an independent strong faction, because their exceptional backgrounds tend to provide abundant political capital and allow them to be leaders in their own right. Princelings suffer from low cohesion because of their complex personal interactions, lack of common corporate experience, and their parents' past animosity and timeworn friendships (Bo, 2004; He and Gao, 1992). Therefore, we code each princeling separately instead of as a coherent faction. All the

remaining officials are considered politically weak. ${ }^{8}$ Using information on leaders' factional affiliations, we create five dichotomous variables to capture the possible factional combinations during power transitions. For instance, when testing the effect of the Type I power transitions, the dichotomous variable equals 1 when the predecessor and the incumbent belong to different strong factions and 0 for all other combinations. Figure 3 reveals that between 1996 and 2012, the different power transition types were relatively evenly distributed.

\section{[Figure 3 about here]}

We control for a rich set of confounding variables associated with the characteristics of provinces and individual party secretaries to minimize the omitted variable bias encountered in 
observational studies. In particular, we control for the level of economic development, measured as the logarithm of per capita gross domestic product (GDP, deflated to constant price in 2000) and that of the number of government officials, because a large number of officials is likely to lead to an increase in the number of corrupt officials. Moreover, we control for the impact of actual corruption on the dependent variable by using two imperfect but arguably reasonable proxies. The first is government size, measured as the ratio of government spending to provincial GDP, because larger government spending has been found to strongly positively influence corruption (Goel \& Nelson, 1998). The second proxy is the share of state-owned enterprises (SOEs) in provincial GDP (i.e., SOE size), because it potentially gauges the degree of government intervention in the market economy, which is argued to be a major cause of corruption (Sun, 2004).

In addition, we control for a dummy variable, Big Case, to address the concern that the increased number of investigated officials may be driven by certain major cases (da yao an) inspected by the CDIC. In such scenarios, the party center rather than the local government targets high-ranking provincial leaders and their local followers. Big Case equals 1 when a province has vice-and-higher provincial-level officials investigated by the CDIC in a particular year, and 0 otherwise. We also include Big Case $(t+1)$ and Big Case $(t+2)$ in the model to denote one and two years following the big case, respectively, because big cases can increase local corruption investigation in subsequent years. In the robustness check, we further control for several personal characteristics of party secretaries, such as age, education, years of party membership, and local working experience, and a set of other variables that are detailed later. Table 1 summarizes our data and Table A1 (online appendix) reports the data sources and definitions. 


\section{[Table 1 about here]}

\section{Model Specification}

Given the relatively large scale of our dependent variable (mean $=83$ ), we use linear regressions for major regressions and report in the appendix the results of the negative binominal model for a robustness check. In particular, we employ a fixed effect model, which enables us to focus on the within-province variations of anticorruption activity associated with the different types of power transitions. In addition, the fixed effect model enables us to eliminate unobservable time-invariant or slow-changing confounders. If we assume that the level of corruption changes very slowly in a province, a fixed effect model would be particularly useful for controlling for the effect of corruption level. Our baseline model specification is as follows:

$$
y_{i t}=\alpha+\beta P_{i t}+\lambda \mathbf{X}_{i t}+\eta_{i}+\theta_{t}+\varepsilon_{i t}
$$

where $i$ indexes province and $t$ indexes year; $y_{i t}$ is our dependent variable, that is, the number of officials at and above county/division levels investigated by the provincial procuratorates; $P_{i t}$ is the dichotomous measure of a particular type of power transition (we primarily focus on Type I strong/strong-contender power transitions); $\mathbf{X}_{i t}$ is a vector of temporal control variables introduced in the preceding section; $\alpha, \beta$, and $\boldsymbol{\lambda}$ are parameters to be estimated; $\eta_{i}$ is the province fixed effect; $\theta_{t}$ is the year fixed effect parameter; and $\varepsilon_{i t}$ is the error term.

Equation (1) estimates the average effect of a certain type of power transition on anticorruption endeavors. To further probe the precise timing of enhanced anticorruption efforts, we include lags and leads of power transition and employ a flexible specification: 


$$
y_{i t}=\sum_{\tau \in[-2,5+], \tau \neq 0} \beta_{\tau} P_{i, \tau}^{\prime}+\lambda \mathbf{X}_{i t}+\eta_{i}+\theta_{t}+\varepsilon_{i t},
$$

where $P_{i, \tau}^{\prime}$ is a set of dummy variables equaling 1 if $\tau$ years have passed since the power transition. Here, $\tau \in[-2,5+]$ specifies the "event window" of power transition: $5+$ and -2 indicates more than five years after and two years before the event, respectively. If $\beta_{-1}$ and $\beta_{-2}$ are insignificant, we have confidence that the estimates are not driven by the omitted temporal factors simultaneously causing power transition and anticorruption endeavors. Throughout, we report province-clustered standard errors to account for within-province correlations, including serial autocorrelation, in panel data.

\section{Estimation Results}

\section{Baseline Results}

The baseline results in Table 2 reveal striking patterns. Column (1) shows that without any control variables, the estimated coefficient for Type I power transitions is significant at conventional levels. Column (2) contains results obtained after controlling for the number of government officials (logged) and the per capita GDP (logged). We further control the two proxies for corruption in columns (3), and control for Big Case effects in column (4). The estimated results of strong/strong-contender power transition in columns (2)-(4) are robust. The two proxies of actual corruption are indistinguishable from zero in columns (3)-(4), indicating that anticorruption endeavors may be not a direct response to the degree of local corruption. Column (4) reveals that the effect of Big Case in the year of investigation is positive and significant at the $10 \%$ level. Clearly, an investigation of big cases can increase the number of investigated senior corrupt officials by nine. Yet, this effect diminishes and becomes insignificant in the two subsequent years. Our findings suggest that strong/strong-contender 
power transition can on average significantly increase the number of investigated officials annually by $13-17$, which, given that the average number of investigated officials in our sample is 83 , is equivalent to an approximately $15 \%-20 \%$ increase relative to the mean. ${ }^{9}$

\section{[Table 2 about here]}

To further test our hypothesis, we examine the effect of other types of power transitions on anticorruption investigations; Table 3 presents the results. Columns (1) and (2) show that when the incumbent and the predecessor belong to the same faction, the incumbent has less incentive to investigate many corrupt local officials; this is consistent with our hypothesis. Although this effect cannot be precisely estimated in column (1), it is significant when baseline controls are added in column (2). Moreover, columns (3)-(6) suggest that none of the estimated coefficients of the other types of power transitions are significant. These findings affirm our hypothesis: power competition between incumbents and predecessors rather than belonging to a strong faction per se motivates provincial leaders to investigate corrupt local officials. We also use "weak/weak" as the reference category and include the other four types in the model. The results are reported in Table A2.

\section{[Table 3 about here]}

\section{Robustness Checks}

We perform a series of regressions to test the robustness of our findings. In column (1) of Table 4, we exclude the four centrally-administered municipalities (i.e., Beijing, Tianjin, Shanghai, and Chongqing) from our sample to preclude the possibility that our findings are driven by these large municipalities. In column (2), we remove Tibet and Xinjiang because the logic of anticorruption campaigns in these ethnic minority regions may diverge from the identified pattern. In column (3), we further narrow our sample to the Hu-Wen Administration 
between 2002 and 2012 to test the pattern in the most recent years. In addition, we allow the time effects to differ across regions and control region-year fixed effects in column (4). ${ }^{10}$ The results in columns (1)-(4) reveal that the effect of Type I power transitions remains robust and similar to the baseline findings. Column (5) includes province-specific time trends and controls for smooth trends in any unobserved confounders that vary temporally at the provincial level. This conservative method for addressing potential endogeneity barely alters our basic findings, although the effect of strong/strong-contender power transitions unsurprisingly decreases. Moreover, if we relax our assumption so that the level of corruption follows a linear trend, then this model specification can help us control for the effect of corruption level. Finally, we calculate the log of our dependent variable to reduce its potential skewness in column (6). The result indicates that a strong/strong-contender power transition is associated with an approximately $14 \%$ increase in the number of investigated officials, which is consistent with our baseline findings.

\section{[Table 4 about here]}

To further test the robustness of our findings, we add more control variables to the baseline specification in Table 5. First, we incorporate the lagged dependent variable in the regression to check against mean-reverting dynamics. Because the model with the lagged dependent variable and province effects yields inconsistent estimates unless the time dimension is infinity (Nickel, 1981), we employ the generalized method of moment in column (1) to ensure consistency (Arellano \& Bond, 1991). To account for the effect of formal institutions on fighting corruption, we include "judicial expenditure," measured as the share of expenses on police, procuratorate, court, and judiciary in total government spending, as an imperfect but defensible proxy in column (2). ${ }^{11}$ In addition, drawing on the data set of the 2002 Asian Barometer Survey I 
(ABSI), we construct two direct measures of corruption, namely local residents' average corruption perception and corruption experience, to further control levels of actual corruption in each province. For this test, we consider the period 2002-2012 and treat the 2002 data as the initial values of the corruption indicators. In columns (3)-(4), we flexibly interact these two variables with year fixed effects as the control variables. This flexible but demanding approach enables us to check against time-varying effects of the initial levels of corruption. ${ }^{12}$ Therefore, this strategy can effectively control for the level of corruption by assuming that its change over time is a function of its initial level. Finally, as discussed previously, authoritarian leaders may launch anticorruption campaigns in response to public dissatisfaction. To account for this possibility, we flexibly interact the year dummies with the average political trust of central and local governments in 2002, drawn from the ABSI data set, as the control variables in columns (5)-(6). Reassuringly, the estimated effect of strong/strong-contender power transition is largely unaffected in all regressions in Table 5.

\section{[Table 5 about here]}

In addition, to account for province heterogeneity and cross-province correlations in our data set, we use panel-corrected standard errors and report the results in Table A3. Table A4 reports estimation results based on negative binomial models. Unsurprisingly, the results of these alternative models are quantitatively similar to those of our baseline regressions.

\section{Role of Personal Characteristics in Fighting Corruption}

In addition to factional ties, the personal traits of party secretaries may influence their incentive to fight corruption. Therefore, we include party secretaries' level of education, age, squared term of age, and years of party membership (columns (1)-(4) of Table 6) in the 
regressions. We find that the estimated coefficients of strong/strong-contender power transition remain significant and stable across the four specifications, whereas none of the personal characteristic variables are significant. In addition, we examine the influence of party secretaries' local working experience on anticorruption endeavors. The results in column (5) reveal that local working experience per se does not significantly influence anticorruption incentives. Yet, when we interact local experience with our key independent variable (strong/strong-contender power transition), the estimated coefficient of the interaction term is significantly negative as seen in column (6); the joint estimate of strong/strong-contender power transition and the interaction term is only 2.6 and insignificant, suggesting that if incumbents from strong factions have worked in a particular locality for a long period, they are unlikely to fight corruption aggressively, even if their predecessors belong to a competing strong faction. This finding further lends credence to our theoretical argument that subnational political leaders fight corruption largely to dismantle the political networks of their predecessors and to consolidate power. Leaders who have already built their political networks through their career trajectories in a locality face few local threats and have low motivation to fight corruption. ${ }^{13}$

\section{[Table 6 about here]}

\section{Dynamics of Anticorruption}

Using Equation (2), we examine the dynamic effects of anticorruption. As portrayed in Figure 4, prior to Type I power transitions and during the first year of the incumbent's tenure, no increase is seen in the number of investigated officials. In the second year, the number of investigated officials increases but the effect is insignificant. From the third year onward, we clearly witness a sizable increase in the dependent variable. The coefficients range from 24.2 to 31.9 and are generally significant. This pattern suggests that even incumbents from strong 
factions do not attack their competitors and remove established political networks immediately after assuming the post, most likely because gaining control of the anticorruption apparatus and collecting "smoking gun" corruption evidence may take time. The finding that Type I power transitions occur two years before anticorruption campaigns supports our position that local anticorruption endeavors are not driven by underlying factors that simultaneously cause both power transitions and a surge in the number of investigated officials.

\section{[Figure 4 about here]}

\section{Ancillary Evidence}

Thus far, all our analyses considered the number of investigated officials as the dependent variable. To further address the primary concern over the accurate measurement of anticorruption endeavors, we employ a complementary measurement: local governments' anticorruption propaganda. Local party secretaries tend to use party mouthpieces to rally anticorruption campaigns (Manion, 2004). Stronger anticorruption efforts are most likely reflected in increased relevant news reports in provincial party newspapers. Therefore, we examine anticorruption propaganda to supplement our main analysis. We compile a data set of annual counts of provincial party newspaper article titles between 2003 and 2012 containing the phrases “corruption” (fubai), “anticorruption” (fanfubai), and “clean government” (lianzheng). In addition to these three indicators, we add the indicators to construct a new variable, "all," to capture the overall intensity of the anticorruption propaganda. Because the dependent variable is count data and the mean value of these indicators is less than 20 , we employ the negative binomial model. The results in Table 7 show that while strong/strong-contender power transitions cannot account for the instances of "corruption" or "anticorruption," they are associated with a positive and significant increase in the instances of "clean government" and the 
total number of relevant news articles. The marginal effects suggest that Type I power transitions can lead to an annual increase of up to five articles concerning anticorruption propaganda, which is equivalent to a $34 \%-40 \%$ increase relative to the mean. Moreover, on testing the effects of other types of power transitions, we find that only weak/weak transitions are negatively associated with anticorruption propaganda (Table A5).

\section{[Table 8 about here]}

Figure 5 illustrates the dynamic effect of strong/strong-contender power transitions on anticorruption propaganda in newspapers. The estimated effect of Type I power transitions on the number of articles titled "clean government" begins to increase in the first year of the incumbent's tenure, but is insignificant at the $5 \%$ level. From the second to the fourth year, the estimated effects are positive and significant. From the fifth year onward, the effect begins to decline (Figure 5A). Similar patterns exist for all three phrases (Figure 5B). The overall trend is consistent with our theoretical prediction. We also conduct a placebo test using illegal fund (weiji jin'e) audited in total fiscal expenditure. Details of this test and results are available in the online appendix (Table A6).

\section{[Figure 5 about here]}

In general, we empirically document that strong/strong-contender power transitions are associated with higher anticorruption endeavors at the provincial level in China, which is reflected not only in the number of investigated officials but also in the intensity of anticorruption propaganda. Political leaders with local political networks are found to be unlikely to fight corruption, suggesting that anticorruption drives primarily aim to remove the political network of rivals and to consolidate power. Our empirical results are robust to various specifications and estimation strategies. 


\section{Discussion and Conclusion}

The purpose of this study was to understand the motivations behind anticorruption drives initiated by authoritarian leaders. We argue that intraelite power competition in authoritarian regimes can lead to the politicization of anticorruption just as partisan competition does in democracies. Specifically, we find that during provincial leadership turnovers in China, the incentive to politicize anticorruption is the strongest when outgoing party secretaries and their incumbents belong to competing strong factions, because intraelite power competition tends to be the most intense. Thus, as argued by Yang (2004, 250), the motivations behind power struggles among political elites in authoritarian regimes "can over time play a role in combating corruption similar to that played by interparty competition in political systems with open political contestation.”

Our research contributes to the understanding of both authoritarian regimes in general and corruption control in China. Several scholars have observed that although corruption is serious in China, periodic anticorruption campaigns have managed to restrain it (Manion, 2004; Wedeman, 2012). However, little research has systematically investigated the mechanism encouraging the Chinese government to combat corruption. Without assuming the benevolence of either central or provincial government officials, we show that elite power competition along factional lines can periodically stimulate intensive corruption investigations. Although such anticorruption campaigns tend to be political and selective, they nevertheless maintain corruption under a certain level.

Broadly, our findings reveal that informal political networks, represented by factional infighting within the ruling party, can advance anticorruption movements. This is especially germane to nondemocracies, which usually lack effective institutions to guarantee an 
independent check on corruption (Chang \& Golden, 2010). In addition, extant literature offers many explanations for why dictators tolerate corruption (Bueno de Mesquita et al., 2003; Shirk, 1993) but provides limited insights into the conditions under which autocrats choose to prosecute those involved. Our theoretical framework explains both tolerance and prosecution. Finally, our study brings a new perspective to the literature on political cycles. Most research has focused on the political impact of leadership turnovers on economic policies in democracies. Our research, in line with other recent studies (Berdejó \& Yuchtman, 2013; Guo, 2009), indicates that cyclical leadership turnovers, regardless of regime type, can influence noneconomic policy areas, such as government anticorruption drives.

Certain limitations exist in our research. First, our findings may not be generalizable to all authoritarian regimes. Future research can offer a nuanced analysis of corruption control motivations in autocracies with strong personal dominance and scant institution building. Second, we are aware of the influence of the party center on local anticorruption endeavors. We have attempted to minimize this influence by controlling time fixed effects to account for anticorruption campaigns initiated by the party center as common shocks to all provinces. Furthermore, political elites at the party center focus primarily on corruption among highranking officials, which we have accounted for by controlling the Big Case dummy variable. Local anticorruption is undeniably influenced more by the party center after Xi Jinping assumed power at the end of 2012. He launched a large-scale anticorruption campaign and strongly empowered the CDIC by strengthening the central circuit teams' inspection scope, intensity, and frequency (Guo, 2014). However, we notice that the CDIC, headed by Wang Qishan, has criticized several times the corruption-condoning attitude of some provincial party secretaries and emphasized their ultimate responsibility in supervising local corruption. ${ }^{14}$ The critique 
reveals the substantial amount of autonomy available to local party committees regarding anticorruption. The party center's top-down momentum relies on local leaderships to effectively fight corruption. Nevertheless, the logic of anticorruption during Xi's rule may differ from our hypothesis and requires additional studies.

Overall, our work presents intraelite power competition as a crucial factor influencing anticorruption activities in authoritarian states. Factional infighting may facilitate balancing the power among the major political elites and maintaining collective rule in a one-party regime. Moreover, institutional development can be conducive to rationalizing elite competition, preventing it from devolving into destructive power struggles. However, corruption investigations induced by intraelite competition are undeniably biased, arbitrary, and selective. Systemic eradication of corruption depends on independent, transparent, and effective institutions.

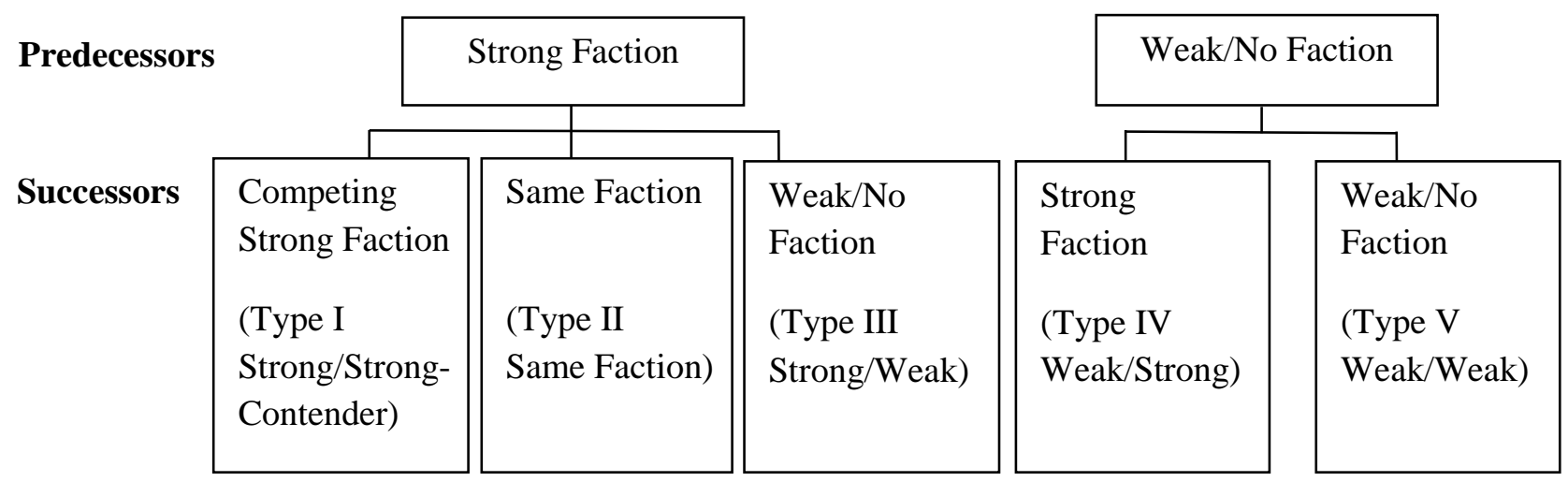

Figure 1. Types of power transition between predecessors and successors 
Figure 2A

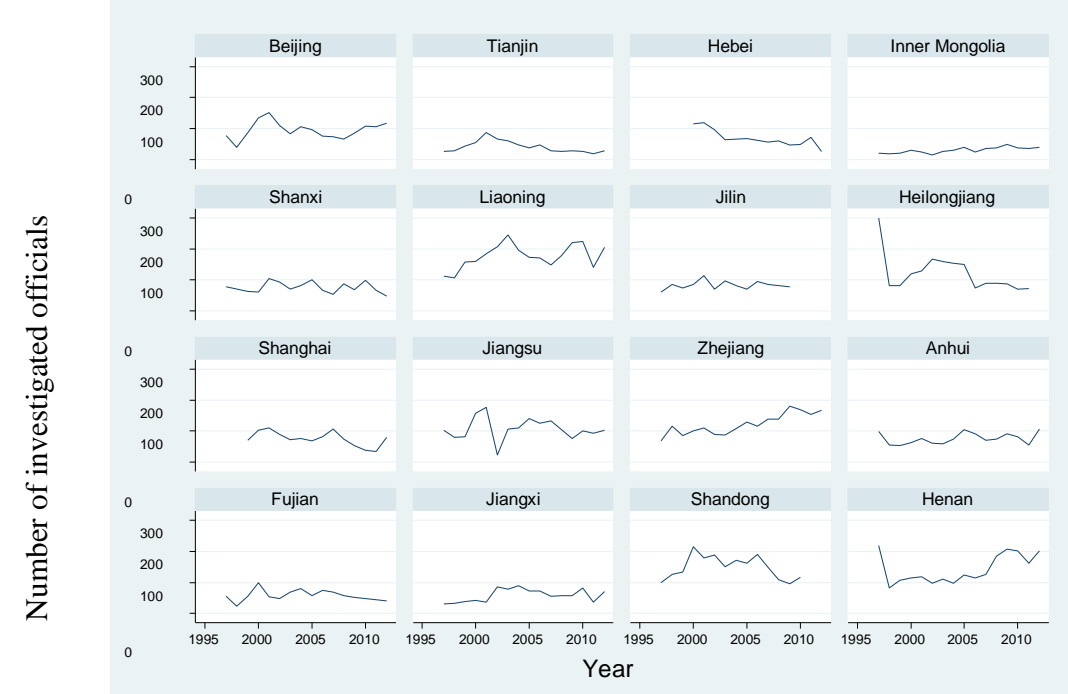

Figure 2B 


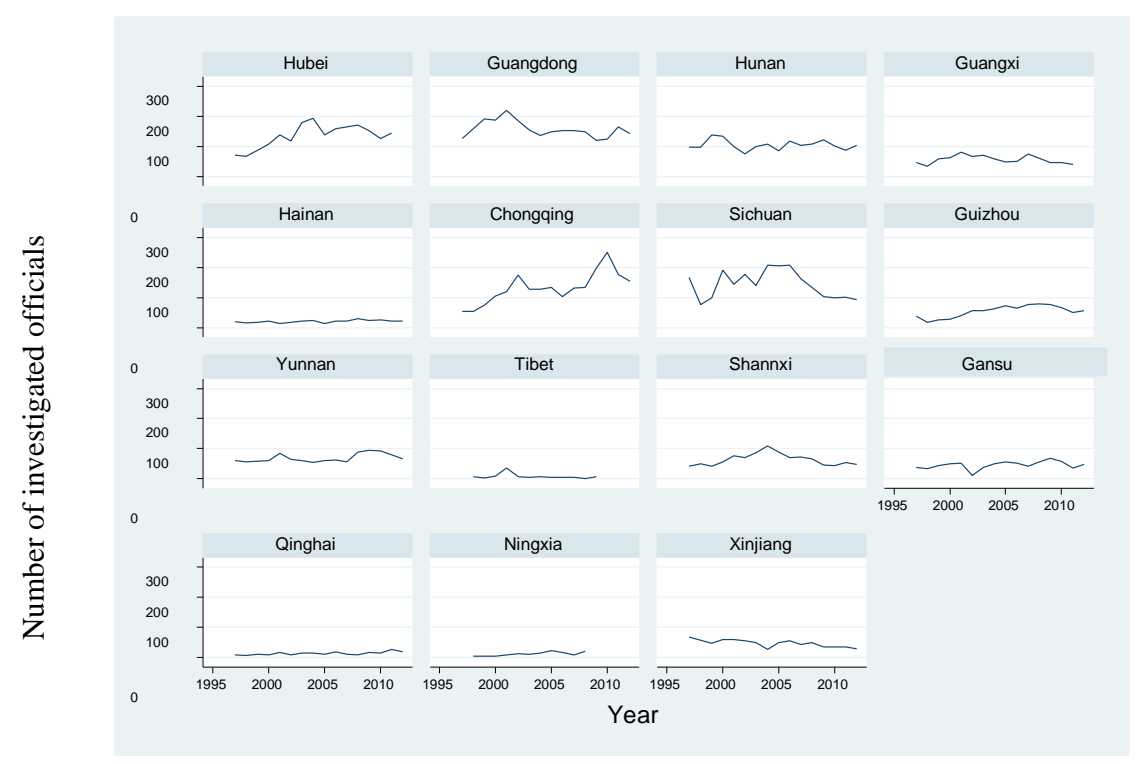

Figure 2. Number of investigated officials across provinces, 1996-2012

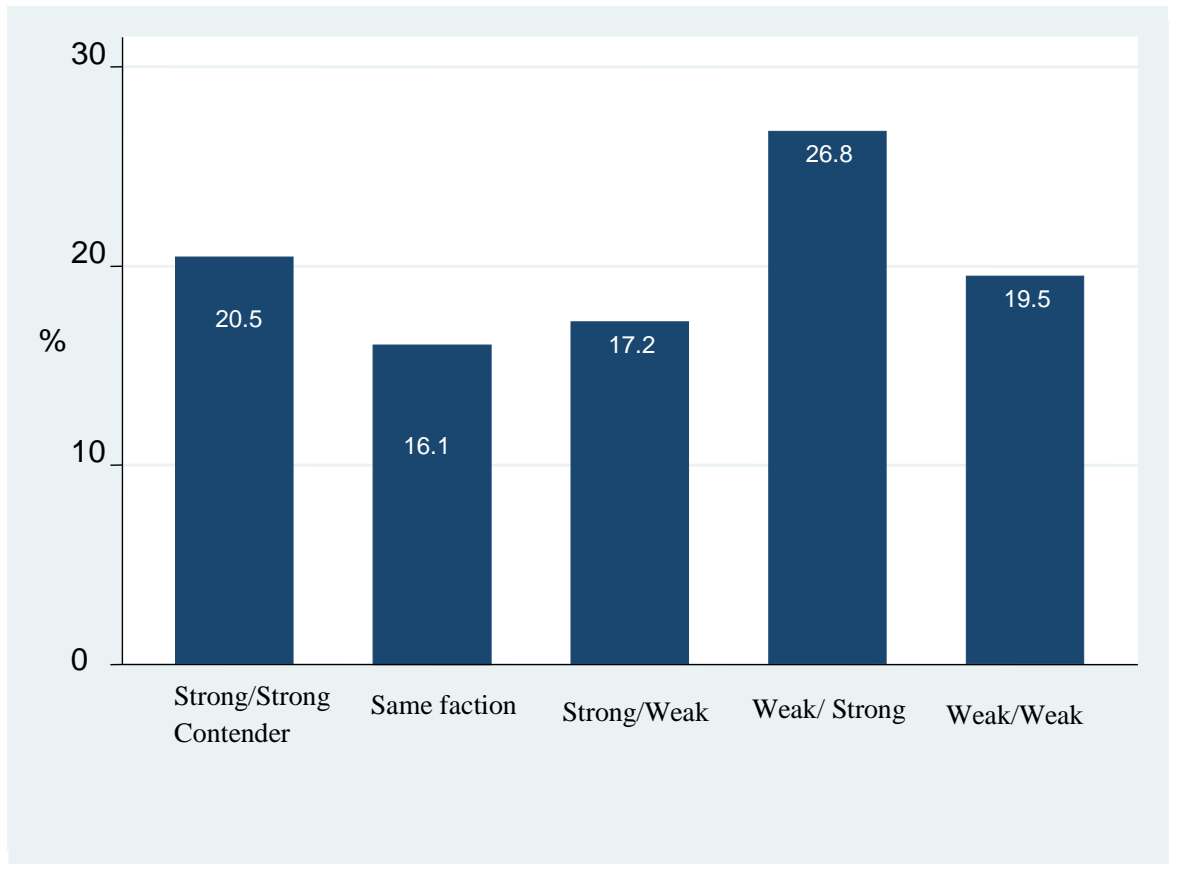

Figure 3. Factional combinations during provincial party secretary power transitions, 19962012 


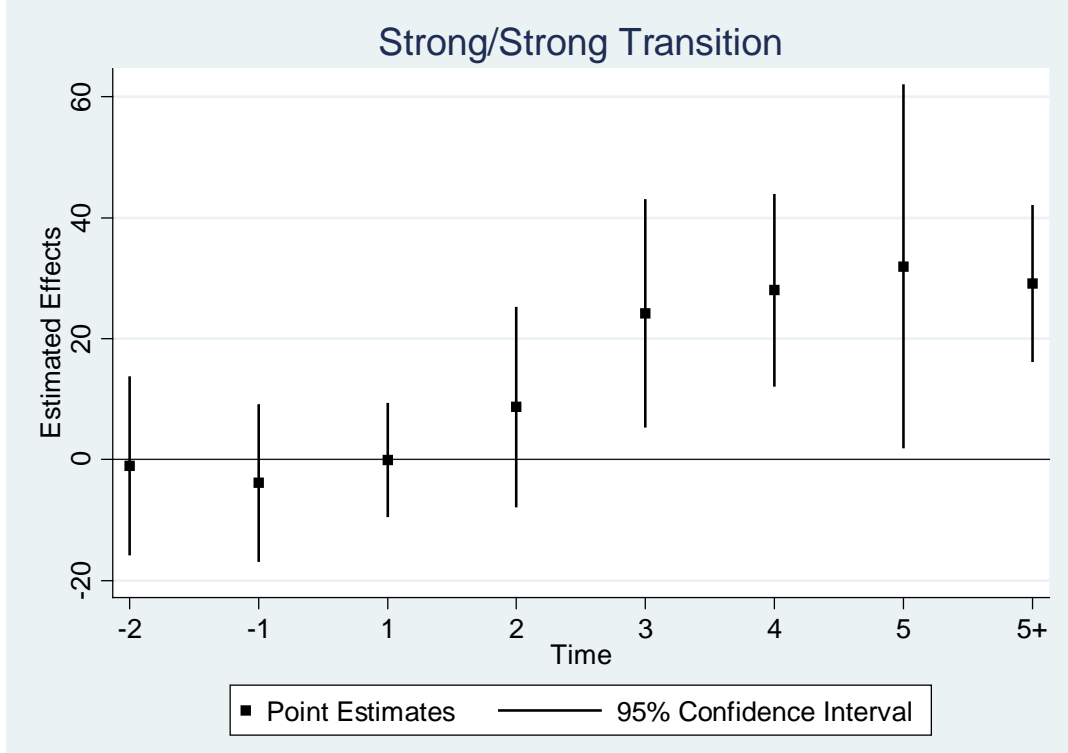

Figure 4. Dynamic effect of Type I strong/strong-contender power transition 
Figure A

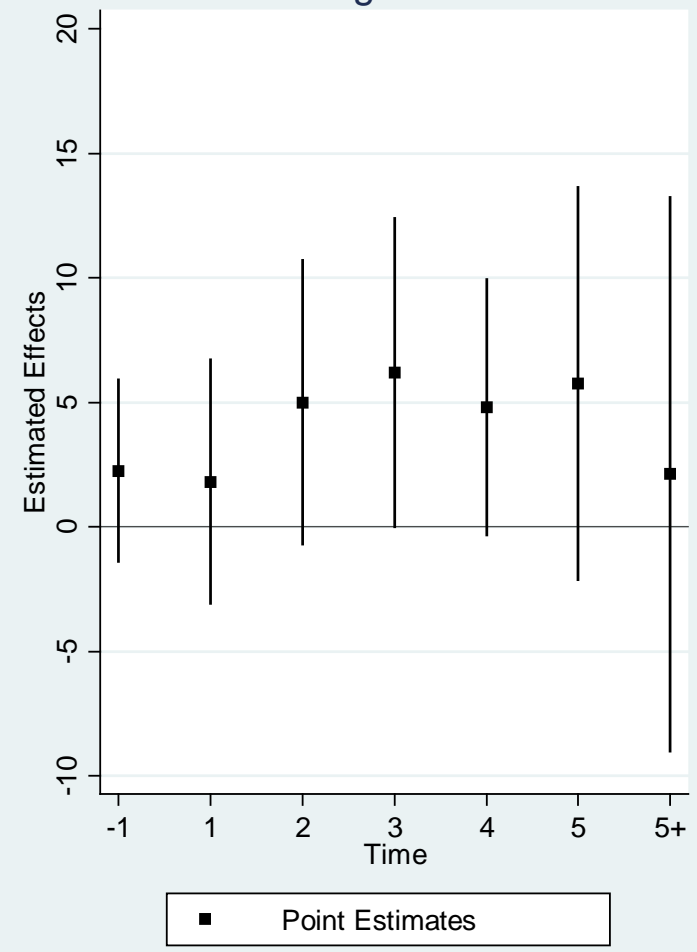

Figure B

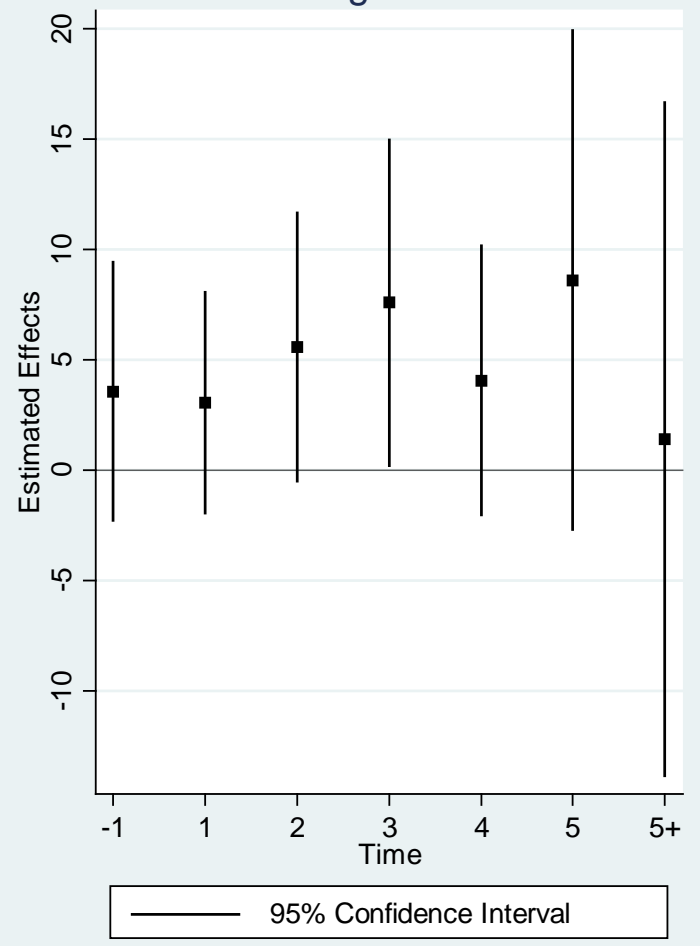

Figure 5. Dynamic effect of Type I strong/strong-contender power transition on newspaper anticorruption propaganda

Table 1. Descriptive statistics 


\begin{tabular}{cccccc}
\hline Variable & Obs & Mean & SD & Min & Max \\
\hline \hline Number of investigated officials & 498 & 83.03 & 53.12 & 1 & 299 \\
Big Case & 527 & 0.10 & 0.30 & 0 & 1 \\
Strong/strong-contender & 523 & 0.21 & 0.40 & 0 & 1 \\
Same faction & 523 & 0.16 & 0.37 & 0 & 1 \\
Strong/weak & 523 & 0.17 & 0.38 & 0 & 1 \\
Weak/strong & 523 & 0.27 & 0.44 & 0 & 1 \\
Weak/weak & 523 & 0.20 & 0.40 & 0 & 1 \\
Ln(number of officials) & 526 & 3.46 & 0.73 & 1.48 & 4.68 \\
SOE size & 498 & 30.66 & 22.21 & 3.87 & 90.27 \\
Ln(per capita GDP) & 527 & 9.00 & 0.52 & 7.88 & 10.54 \\
Government size & 527 & 18.75 & 14.39 & 5.15 & 129.10 \\
Education & 526 & 2.36 & 0.61 & 1 & 4 \\
Local & 526 & 0.38 & 0.49 & 0 & 1 \\
Age & 526 & 59.34 & 4.20 & 47 & 70 \\
Judicial expenditure & 525 & 6.45 & 1.96 & 2.30 & 29.58 \\
Years of party membership & 525 & 35.47 & 6.07 & 17 & 52 \\
Share of illegal funds & 421 & 17.33 & 14.37 & 0.22 & 81.28 \\
Corruption perception 02 & 28 & 2.47 & 0.24 & 1.76 & 3.18 \\
Corruption experience 02 & 28 & 0.24 & 0.09 & 0.08 & 0.47 \\
Trust on central gov02 & 28 & 5.56 & 0.17 & 5.22 & 5.85 \\
Trust on local gov02 & 28 & 4.40 & 0.33 & 3.39 & 5.50 \\
Corruption (fubai) & 403 & 4.57 & 4.31 & 0 & 24 \\
Anticorruption (fanfubai) & 403 & 1.54 & 2.01 & 0 & 10 \\
Clean government (lianzheng) & 403 & 9.79 & 10.74 & 0 & 78 \\
\hline
\end{tabular}

Table 2. Baseline results for the effect of Type I strong/strong-contender power transition 


\begin{tabular}{|c|c|c|c|c|}
\hline & \multicolumn{4}{|c|}{ Dependent variable: Number of investigated officials } \\
\hline & (1) & (2) & (3) & (4) \\
\hline Strong/Strong-Contender & $\begin{array}{c}13.107^{* *} \\
(5.643)\end{array}$ & $\begin{array}{c}16.376^{* * *} \\
(4.894)\end{array}$ & $\begin{array}{c}17.341^{* * *} \\
(5.414)\end{array}$ & $\begin{array}{c}16.168 * * * \\
(5.533)\end{array}$ \\
\hline Ln(number of officials) & & $\begin{array}{c}10.660 \\
(33.599)\end{array}$ & $\begin{array}{c}13.763 \\
(36.873)\end{array}$ & $\begin{array}{c}8.736 \\
(37.796)\end{array}$ \\
\hline Ln(per capita GDP) & & $\begin{array}{c}50.848 * * * \\
(17.088)\end{array}$ & $\begin{array}{c}52.651^{* * *} \\
(18.545)\end{array}$ & $\begin{array}{c}53.525^{* * *} \\
(18.092)\end{array}$ \\
\hline Government size & & & $\begin{array}{l}-0.001 \\
(0.363)\end{array}$ & $\begin{array}{c}0.065 \\
(0.352)\end{array}$ \\
\hline SOE size & & & $\begin{array}{c}0.025 \\
(0.159)\end{array}$ & $\begin{array}{c}0.015 \\
(0.162)\end{array}$ \\
\hline Big Case(t) & & & & $\begin{array}{l}9.558^{*} \\
(5.422)\end{array}$ \\
\hline Big Case $(\mathrm{t}+1)$ & & & & $\begin{array}{c}7.139 \\
(5.449)\end{array}$ \\
\hline Big Case $(t+2)$ & & & & $\begin{array}{l}-0.854 \\
(3.806)\end{array}$ \\
\hline Observations & 495 & 495 & 471 & 471 \\
\hline Number of provinces & 31 & 31 & 31 & 31 \\
\hline Adjusted R-squared & 0.086 & 0.112 & 0.116 & 0.126 \\
\hline Province FE & YES & YES & YES & YES \\
\hline Year FE & YES & YES & YES & YES \\
\hline
\end{tabular}

Notes: Robust standard errors clustered at the provincial level shown in parentheses.

$* * *$ Significance at $1 \% * *$ Significance at $5 \% *$ Significance at $10 \%$

Table 3. Effect of other power transition types 


\begin{tabular}{|c|c|c|c|c|c|c|c|c|}
\hline & \multicolumn{2}{|c|}{ Same faction } & \multicolumn{2}{|c|}{ Strong/weak } & \multicolumn{2}{|c|}{ Weak/strong } & \multicolumn{2}{|c|}{ Weak/weak } \\
\hline & (1) & $(2)$ & (3) & (4) & (5) & (6) & (7) & $(8)$ \\
\hline Power transition & $\begin{array}{c}-10.401 \\
(8.205)\end{array}$ & $\begin{array}{c}-15.098^{* *} \\
(7.385)\end{array}$ & $\begin{array}{c}0.888 \\
(4.192)\end{array}$ & $\begin{array}{l}-0.267 \\
(3.830)\end{array}$ & $\begin{array}{l}-1.098 \\
(4.488)\end{array}$ & $\begin{array}{c}0.368 \\
(4.742)\end{array}$ & $\begin{array}{l}-4.448 \\
(6.168)\end{array}$ & $\begin{array}{l}-4.401 \\
(6.764)\end{array}$ \\
\hline Observations & 498 & 474 & 495 & 471 & 495 & 471 & 495 & 471 \\
\hline $\begin{array}{l}\text { Number of } \\
\text { provinces }\end{array}$ & 31 & 31 & 31 & 31 & 31 & 31 & 31 & 31 \\
\hline $\begin{array}{l}\text { Adjusted R- } \\
\text { squared }\end{array}$ & 0.084 & 0.124 & 0.063 & 0.094 & 0.063 & 0.094 & 0.066 & 0.096 \\
\hline Province FE & YES & YES & YES & YES & YES & YES & YES & YES \\
\hline Year FE & YES & YES & YES & YES & YES & YES & YES & YES \\
\hline Baseline controls & NO & YES & NO & YES & NO & YES & NO & YES \\
\hline
\end{tabular}

Notes: Robust standard errors clustered at the provincial level shown in parentheses. Baseline controls include all control variables specified in the column (6) of Table 3. ***Significance at $1 \% * *$ Significance at $5 \%$ *Significance at $10 \%$

Table 4. Robustness checks I 


\begin{tabular}{lcccccc}
\hline & $\begin{array}{c}\text { Excluding } \\
\text { central-direct- } \\
\text { administered } \\
\text { municipalities } \\
(1)\end{array}$ & $\begin{array}{c}\text { Excluding } \\
\text { Tibet and } \\
\text { Xinjiang }\end{array}$ & $\begin{array}{c}\text { Period } \\
2002- \\
2012\end{array}$ & $\begin{array}{c}\text { With } \\
\text { region } \times \\
\text { year FE }\end{array}$ & $\begin{array}{c}\text { With } \\
\text { province- } \\
\text { specific } \\
\text { time trend } \\
(2)\end{array}$ & $\begin{array}{c}\text { DV: } \\
\text { Ln(corruption) }\end{array}$ \\
\hline Strong/Strong- & & & & & & $(4)$ \\
Contender & $15.323^{* *}$ & $17.077^{* * *}$ & $15.577^{* *}$ & $17.371^{* *}$ & $13.076^{* *}$ & $0.143^{* * *}$ \\
& $(6.679)$ & $(5.598)$ & $(7.351)$ & $(6.361)$ & $(5.903)$ & $(0.043)$ \\
Observations & & & & & & \\
Number of provinces & 410 & 442 & 299 & 471 & 471 & 471 \\
Adjusted R-squared & 27 & 29 & 31 & 31 & 31 & 31 \\
Province FE & 0.112 & 0.135 & 0.128 & 0.108 & 0.330 & 0.168 \\
Year FE & YES & YES & YES & YES & YES & YES \\
Baseline controls & YES & YES & YES & YES & YES & YES \\
\hline
\end{tabular}

Notes: Robust standard errors clustered at the provincial level shown in parentheses. The dependent variable in columns (1)-(5) is the number of investigated officials. ***Significance at $1 \% * *$ Significance at $5 \% *$ Significance at $10 \%$

Table 5. Robustness check II 


\begin{tabular}{|c|c|c|c|c|c|c|}
\hline & \multicolumn{6}{|c|}{ Dependent variable: number of investigated officials } \\
\hline & $(1)$ & (2) & (3) & (4) & (5) & (6) \\
\hline Strong/Strong-Contender & $\begin{array}{c}15.865^{* * *} \\
(5.342)\end{array}$ & $\begin{array}{c}16.346^{* * * *} \\
(5.582)\end{array}$ & $\begin{array}{c}14.675^{*} \\
(7.403)\end{array}$ & $\begin{array}{c}16.618^{* *} \\
(7.954)\end{array}$ & $\begin{array}{c}17.177^{* *} \\
(7.878)\end{array}$ & $\begin{array}{c}16.773^{* *} \\
(7.338)\end{array}$ \\
\hline Corruption $_{(\mathrm{t}-1)}$ & $\begin{array}{c}0.325^{* * *} \\
(0.051)\end{array}$ & & & & & \\
\hline Judicial expenditure & & $\begin{array}{c}0.146 \\
(0.857)\end{array}$ & & & & \\
\hline Corruption perception $02 \times$ Year FE & & & YES & & & \\
\hline Corruption experience $02 \times$ Year FE & & & & YES & & \\
\hline Trust on central gov02 $\times$ Year FE & & & & & YES & \\
\hline Trust on local gov02 $\times$ Year FE & & & & & & YES \\
\hline Observations & 448 & 470 & 273 & 273 & 273 & 273 \\
\hline Number of provinces & 31 & 31 & 28 & 28 & 28 & 28 \\
\hline Adjusted R-squared & & 0.128 & 0.163 & 0.140 & 0.125 & 0.153 \\
\hline Province FE & YES & YES & YES & YES & YES & YES \\
\hline Year FE & YES & YES & YES & YES & YES & YES \\
\hline Baseline controls & YES & YES & YES & YES & YES & YES \\
\hline
\end{tabular}

Notes: Robust standard errors clustered at the provincial level shown in parentheses.

***Significance at $1 \% * *$ Significance at $5 \% *$ Significance at $10 \%$ 
Table 6. Personal characteristics and anticorruption endeavors

\begin{tabular}{|c|c|c|c|c|c|c|}
\hline & \multicolumn{6}{|c|}{ Dependent variable: number of investigated officials } \\
\hline & (1) & $(2)$ & (3) & (4) & (5) & (6) \\
\hline Strong/Strong-Contender & $\begin{array}{l}16.193 * * * \\
(5.552)\end{array}$ & $\begin{array}{l}17.360^{* * *} \\
(5.817)\end{array}$ & $\begin{array}{l}17.588^{* * *} \\
(6.016)\end{array}$ & $\begin{array}{l}16.189 * * * \\
(5.547)\end{array}$ & $\begin{array}{c}16.356^{* *} \\
(5.949)\end{array}$ & $\begin{array}{l}21.274^{* * * *} \\
(7.366)\end{array}$ \\
\hline Education & $\begin{array}{l}-0.897 \\
(3.752)\end{array}$ & & & & & \\
\hline Age & & $\begin{array}{c}0.718 \\
(0.562)\end{array}$ & $\begin{array}{c}-4.501 \\
(11.916)\end{array}$ & & & \\
\hline $\mathrm{Age}^{2}$ & & & $\begin{array}{c}0.045 \\
(0.104)\end{array}$ & & & \\
\hline Years of party membership & & & & $\begin{array}{c}0.058 \\
(0.466)\end{array}$ & & \\
\hline Local & & & & & $\begin{array}{c}0.865 \\
(4.842)\end{array}$ & $\begin{array}{c}3.439 \\
(5.689)\end{array}$ \\
\hline $\begin{array}{l}\text { Local } \times \text { strong/strong- } \\
\text { contender }\end{array}$ & & & & & & $\begin{array}{c}-18.673^{*} \\
(9.926)\end{array}$ \\
\hline $\begin{array}{l}\text { Strong/strong } \\
+(\text { local } \times \text { strong/strong })\end{array}$ & & & & & & $\begin{array}{c}2.601 \\
(6.435)\end{array}$ \\
\hline Observations & 471 & 471 & 471 & 470 & 471 & 471 \\
\hline Number of provinces & 31 & 31 & 31 & 31 & 31 & 31 \\
\hline Adjusted R-squared & 0.124 & 0.133 & 0.132 & 0.123 & 0.124 & 0.131 \\
\hline Province FE & YES & YES & YES & YES & YES & YES \\
\hline Year FE & YES & YES & YES & YES & YES & YES \\
\hline Baseline controls & YES & YES & YES & YES & YES & YES \\
\hline
\end{tabular}

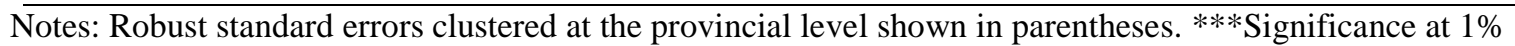
** Significance at $5 \% *$ Significance at $10 \%$ 
Table 7. Effect of Type I strong/strong-contender power transition on anticorruption propaganda

\begin{tabular}{|c|c|c|c|c|}
\hline & $\begin{array}{c}(1) \\
\text { Fubai } \\
\text { (corruption) }\end{array}$ & $\begin{array}{c}(2) \\
\text { Fanfubai } \\
\text { (anticorruption) }\end{array}$ & $\begin{array}{c}(3) \\
\text { Lianzheng } \\
\text { (clean } \\
\text { government) }\end{array}$ & $\begin{array}{l}\text { (4) } \\
\text { All } \\
\end{array}$ \\
\hline Strong / Strong-Contender & $\begin{array}{c}0.094 \\
(0.149)\end{array}$ & $\begin{array}{c}0.107 \\
(0.204)\end{array}$ & $\begin{array}{l}0.342 * * \\
(0.159)\end{array}$ & $\begin{array}{l}0.298 * * \\
(0.137)\end{array}$ \\
\hline Marginal effects & $\begin{array}{c}0.531 \\
(0.856)\end{array}$ & $\begin{array}{c}0.195 \\
(0.383)\end{array}$ & $\begin{array}{l}4.804^{* *} \\
(2.430)\end{array}$ & $\begin{array}{l}5.378^{* *} \\
(2.634)\end{array}$ \\
\hline Ln(number of officials) & $\begin{array}{l}-0.954 \\
(1.186)\end{array}$ & $\begin{array}{l}-0.645 \\
(1.734)\end{array}$ & $\begin{array}{c}-2.898 * * \\
(1.393)\end{array}$ & $\begin{array}{c}-2.296 * \\
(1.268)\end{array}$ \\
\hline Ln(per capita GDP) & $\begin{array}{c}1.211^{* * *} \\
(0.467)\end{array}$ & $\begin{array}{l}1.498^{*} \\
(0.810)\end{array}$ & $\begin{array}{c}1.023 \\
(0.628)\end{array}$ & $\begin{array}{c}0.967 * * \\
(0.459)\end{array}$ \\
\hline Big Case(t) & $\begin{array}{c}0.298^{* * *} \\
(0.097)\end{array}$ & $\begin{array}{c}0.272 \\
(0.181)\end{array}$ & $\begin{array}{c}0.315^{* * *} \\
(0.091)\end{array}$ & $\begin{array}{c}0.320^{* * *} \\
(0.085)\end{array}$ \\
\hline Big Case $(\mathrm{t}+1)$ & $\begin{array}{c}0.171 \\
(0.113)\end{array}$ & $\begin{array}{c}0.173 \\
(0.184)\end{array}$ & $\begin{array}{c}0.145 \\
(0.102)\end{array}$ & $\begin{array}{l}0.197^{*} \\
(0.104)\end{array}$ \\
\hline Big Case $(\mathrm{t}+2)$ & $\begin{array}{c}0.126 \\
(0.111)\end{array}$ & $\begin{array}{c}0.190 \\
(0.126)\end{array}$ & $\begin{array}{c}0.109 \\
(0.122)\end{array}$ & $\begin{array}{c}0.119 \\
(0.115)\end{array}$ \\
\hline $\begin{array}{l}\text { Observations } \\
\text { Number of provinces }\end{array}$ & $\begin{array}{c}310 \\
31\end{array}$ & $\begin{array}{c}310 \\
31\end{array}$ & $\begin{array}{c}310 \\
31\end{array}$ & $\begin{array}{c}310 \\
31\end{array}$ \\
\hline Province FE & YES & YES & YES & YES \\
\hline Year FE & YES & YES & YES & YES \\
\hline
\end{tabular}

Notes: Robust standard errors clustered at the provincial level shown in parentheses. Marginal effects of strong/strong-contender power transition are calculated using finite difference method. The overdispersion parameter $\alpha$ in all specifications significantly differs from zero. $* * *$ Significance at $1 \% * *$ Significance at $5 \%$ *Significance at $10 \%$

\section{Notes}

1. "CDIC receives surging numbers of corruption reports: letters to some province increased from a few hundred to three thousand every month," http://www.thepaper.cn/newsDetail_forward_1315056 accessed 9 June 2015

2. Consensus building among the top echelon of leadership is greatly emphasized in post-Mao 
China, particularly on the decision making of elite politics. A single powerful leader or faction cannot dictate on personnel appointment (e.g. Lieberthal \& Oksenberg, 1988; Shirk, 1993).

3. For example, Zhou Yongkang, a corrupt former PSC member "helicoptered" several local officials to key positions in Sichuan when being the provincial party secretary and often inspected Sichuan after his promotion. These measures, in addition to his status as the secretary of the central political-legal committee, facilitated preserving his personal networks within Sichuan. Zhou's power network undoubtedly formed an obstacle for his successor, Zhang Xuezhong, a follower of Hu Jintao. Zhang called for active anticorruption efforts after he became the party secretary of Sichuan.

4. It is worth pointing out that assigning Bo to an interior city like Chongqing was mainly to move him out of Beijing and reduce his influence and power, rather than to send him to fight corruption in Chongqing. Reportedly, Wu Yi, the former vice premier, disliked Bo for his arrogance. She retired without seeking any honorary post to exchange for not naming Bo, who was commerce minister at that time, as her successor. Bo's case also reflects that personnel decisions are often the results of contingent factors and compromise between different factions.

5. An analogous example is that Zeng Qinghong attempted to compete for PRC president with Hu Jingtao in 2007. Hu ordered the CDIC to investigate corruption offences of Zeng's son in exchange for Zeng's ultimate withdraw (Guo, 2014).

6. Investigation data of provincial procuratorates appeared in Procuratorate Statistical Yearbooks from 1986. However, data before 1996 have many missing values.

7. We double-check our coding by using biographies of provincial leaders and other publicly available sources, such as the Connected China Database (http://china.fathom.info/). Two researchers independently coded the factional ties of provincial leaders and reconciled the discrepancies to ensure intercoder reliability.

8. Faction details are available on request to the authors. Empirically, even if we treat princelings as one faction, our findings will be unaffected and could even be strengthened. Results are available on request.

9. We further examine the extent to which omitted variables, such as corruption level, may affect our findings according to the insight that the bias from observed controls is informative about the bias from unobserved controls (Altonji, Elder, \& Taber, 2005). We consider the model in column 1 of Table 2 a restricted model and that in column 4 of Table 2 a full model. The lower bound on the true coefficient can be calculated as: $\widehat{\beta}_{\text {low er }}=\widehat{\beta}_{\text {full }}-\left|\left(\widehat{\beta}_{\text {restricted }}-\widehat{\beta}_{\text {full }}\right)\right|$. The lower bound of our estimated effect is: $16.168-$ $|(13.107-16.168)|=13.107$. Following the approach of Bellows and Miguel (2009), we calculate the ratio of the estimated coefficient of the restricted model to the difference in the estimated coefficients between the restricted model and full model. The ratio is 4.28, suggesting that the relationship between the omitted variables and our dependent variable must be more than fourfold stronger to explain the entire effect we have identified. Given that we have accounted for various potential confounding variables including fixed effects, omitted variable bias is unlikely to affect our results.

10. The regions are east, north, south, central, northwest, southwest, and northeast China.

11. We are aware that introducing this variable to the regression may produce potential 
posttreatment bias; we control for the consequences of the treatment variable (e.g., Angrist \& Pischke, 2009; King, 2010).

12. Because we have the direct measure of corruption of only 2002, we include this variable in the robustness check rather than the major regressions.

13. We test the effect of the personal characteristics of provincial governors and their relationship with party secretaries (i.e., whether they are from competing factions) and fail to find consistent and robust results. Regression results are available upon request.

14. "Problems in anticorruption is first attributed to the party secretary", http://xmwb.news365.com.cn/zg/201409/t20140902_1263454.html, accessed 23 May 2015.

Acknowledgement: This project is sponsored by HKGRF (project no. 17411814). We thank Bernard Black, Jordan Gans-Morse, Mingxing Liu, Jie Lu, Xun Pang, Victor Shih, Yiping Wu, for their valuable comments and various support during the research. We also thank the helpful comments from the three anonymous reviewers and the CPS editors, as well as the excellent research assistance from Irina He, Siqin Kang, Charlie Liu, and Xiaoming Zhong.

\section{REFERENCES:}

Ades, A., \& Di Tella R. (1999). Rents, competition, and corruption. American Economic Review, 89 (4), 982-993.

Aidt, T. S. (2009). Corruption, Institutions, and Economic Development. Oxford Review of Economic Policy, 25 (2), 271-291.

Altonji, J. G., Elder, T. E. \& Taber, C. R. (2005). "Selection on Observed and Unobserved Variables: Assessing the Effectiveness of Catholic Schools.” Journal of Political Economy 113, 151-84.

Angrist, J. D., \& Pischke, J.S. (2009). Mostly Harmless Econometrics: An Empiricist's Companion. Princeton: Princeton University Press.

Arellano, M., \& Bond, S.R. (1991). Some Tests of Specification for Panel Data: Monte Carlo Evidence and an Application to Employment Equations. Review of Economic Studies, 58 (2), 277-297.

Bågenholm, A. (2010). Politicizing Corruption: The Electoral Effects of Anti-Corruption Rhetoric in Europe 1983-2007. In APSA: The Quality of Government Institute, Department of Political Science, University of Gothenburg.

Bellows, J. \& Miguel, E. (2009). “War and Local Collective Action in Sierra Leone,” Journal of Public Economics 93, 1144-1157. 
Berdejó, C., \& Yuchtman, N. (2013). Crime, Punishment, and Politics: An Analysis of Political Cycles in Criminal Sentencing. The Review of Economics and Statistics, 95 (3), 741-756.

Bo, Z. (2004). The 16th Central Committee of the Chinese Communist Party: formal institutions and factional groups. Journal of Contemporary China, 13(39), 223-256.

Brownlee, J. (2007). Authoritarianism in an Age of Democratization. Cambridge, UK: Cambridge University Press.

Brunetti, A., \& Beatrice, W. (2003). A Free Press Is Bad News for Corruption. Journal of Public Economics, 87, 1801-1824.

Bueno de Mesquita, B., Smith, A., Siverson, R., \& Morrow, J. (2003). The Logic of Political Survival. Cambridge, MASS: MIT Press.

Chang, E., \& Golden, M. A. (2010). Sources of Corruption in Authoritarian Regimes. Social Science Quarterly, 91 (1), 1-20.

Ezrow, N. M., \& Frantz, E. (2011). Dictators and Dictatorships: Understanding Authoritarian Regimes and Their Leaders. New York: Continuum.

Fewsmith, J. (2001). Elite Politics in Contemporary China. Armonk, NY: M.E. Sharpe.

Fewsmith, J. (2010). Bo Xilai Takes On Organized Crime. China Leadership Monitor, 32, 1-8.

Gandhi, J. (2008). Political Institutions under Dictatorship. Cambridge University Press.

Gandhi, J., \& Przeworski, A. (2007). Authoritarian Institutions and the Survival of Autocrats. Comparative Political Studies, 40 (11), 1279-1301.

Geddes, B. (2003). Paradigms and Sand Castles: Theory Building and Research Design in Comparative Politics. Ann Arbor: University of Michigan Press.

Ghița, I., \& Madariaga, I.D. (1968). Opposition: Past and Present of a Political Institution. London: C.A.Watts.

Gillespie, K., \& Okruhlik, G. (1991). The Political Dimensions of Corruption Cleanups: A Framework for Analysis. Comparative Politics, 24 (1), 77-95.

Gong, T. (1997). Forms and Characteristics of China's Corruption in the 1990s: Change with Continuity. Communist and Post-Communist Studies, 30 (3), 277-288.

Gong, T. (2002). Dangerous Collusion: Corruption as a Collective Venture in Contemporary China. Communist and Post-Communist Studies, 35 (1), 85-103. 
Gordon, S. C. (2009). Assessing Partisan Bias in Federal Public Corruption Prosecutions. American Political Science Review, 103 (4), 534-554.

Guo, G. (2009). China’s Local Political Budget Cycles. American Journal of Political Science, 53 (3), 621-632.

Guo, X. (2014). Controlling Corruption in the Party: China’s Central Discipline Inspection Commission. The China Quarterly, 219, 597-624.

Guo, Y. (2008). Corruption in Transitional China: An Empirical Analysis. The China Quarterly, 194 (1), 349-364.

Haber, S. (2006). Authoritarian Government. In B.R. Weingast, \& D. A. Wittman (Eds.), The Oxford Handbook of Political Economy (pp.693-707). Oxford University Press.

He, P. \& Gao, X. (1992), Zhonggong Taizidang ['CCP’s Princeling Party']. New York, N.Y.:Mirror Books.

Heidenheimer, A. J., \& Johnston, M. (2009). ed. Political Corruption: Concepts \& Contexts. New Brunswick, New Jersey: Transaction Publishers, 5th edition.

Hollyer, J. R., \& Wantchekon, L. (2015). Corruption and Ideology in Autocracies. Journal of Law, Economics, and Organization.

Huang, J. (2000). Factionalism in Chinese Communist Politics. New York: Cambridge University Press.

King, G. (2010). A Hard Unsolved Problem? Post-Treatment Bias in Big Social Science Questions. "Hard Problems in Social Science” Symposium Harvard University.

Ko, K.\& Weng, C. (2011). Critical Review of Conceptual Definitions of Chinese Corruption: A Formal-Legal Perspective. Journal of Contemporary China, 20, 359-378.

Levitsky, S., \& Way, L. (2010). Competitive Authoritarianism: Hybrid Regimes after the Cold War. New York: Cambridge University Press.

Li, C. (2012a). Leadership Transition in the CPC: Promising Progress and Potential Problems. China: An International Journal, 10 (2), 23 - 33.

Li, C. (2012b). The battle for China's top nine leadership posts. The Washington Quarterly, 35(1), 131-145.

Li, C. (2013). A Biographical and Factional Analysis of the Post-2012 Politburo. China Leadership Monitor, 41, 1-17. 
Lieberthal, K., \& Oksenberg, M. (1988). Policy Making in China: Leaders, Structures, and Processes Princeton, New Jersey: Princeton University Press.

Lu, X., \& Landry, P. F. (2014). Show Me the Money: Interjurisdiction Political Competition and Fiscal Extraction in China. American Political Science Review, 108 (3), 706-722.

Lust-Okar, E. (2006). Elections under Authoritarianism: Preliminary Lessons from Jordan. Democratization, 13 (3), 456-471.

Magaloni, B. (2006). Voting for Autocracy: Hegemonic Party Survival and Its Demise in Mexico. New York: Cambridge University Press.

Magaloni, B. (2008). Credible Power-Sharing and the Longevity of Authoritarian Rule. Comparative Political Studies, 41 (4-5), 1-27.

Malesky, E., \& Schuler, P. (2010). Noddling or Needling: Analyzing Delegate Responsiveness in an Authoritarian Parliament. American Political Science Review, 104 (3), 482-502.

Manion, M. (2004). Corruption by Design: Building Clean Government in Mainland China and Hong Kong. Cambridge, MA: Harvard University Press.

Meier, K.J., \& Holbrook, T.M. (1992). I Seen My Opportunities and I Took 'Em:’ Political Corruption in the United States. Journal of Politics, 54 (1), 135-155.

Montinola G., \& Jackman, R. (2002). Sources of corruption: a cross-country study? British Journal of Political Science, 32, 147-170.

Nathan, A. J. (1973). A Factionalism Model for CCP Politics. The China Quarterly, 53, 33-66.

Nathan, A. J. (2003). Authoritarian Resilience. Journal of Democracy, 14 (1), 6-17.

Nickell, S. (1981). Biases in dynamic models with fixed effects. Econometrica, 49 (6), 14171426.

Nye, J.S. Jr. (1967). Corruption and Political Development: A Cost-Benefit Analysis. American Political Science Review, 61 (2), 417-427.

Pei, M. (2006). China's Trapped Transition: The Limits of Developmental Autocracy. Cambridge, Mass.: Harvard University Press.

Peters, J. G., \& Welch, S. (1980). The Effects of Charges of Corruption on Voting Behavior in Congressional Elections. The American Political Science Review, 74 (3), 697-708.

Pye, L. (1981). The Dynamics of Chinese Politics. Cambridge, MA: Oelgschlager, Gunn \& Hain. 
Quah, J. S. T. (1999). Corruption in Asian Countries: Can It Be Minimized? Public Administration Review, 59(6), 483-494.

Rajeev, G. K., \& Nelson, M.A. (1998). Corruption and Government Size: A Disaggregated Analysis. Public Choice, 97(1/2), 107-120.

Rose-Ackerman, S. (1999). Corruption and Government: Causes, Consequences, and Reform. Cambridge, U.K.; New York: Cambridge University Press.

Rose, R., Mishler, W., \& Munro, N. (2011). Popular Support for an Undemocratic Regime: The Changing Views of Russians. Cambridge; New York: Cambridge University Press.

Sandholtz, W., \& Koetzle, W. (2000). Accounting for Corruption: Economic Structure, Democracy, and Trade. International Studies Quarterly, 44, 31-50.

Seligson, M. A. (2002). The Impact of Corruption on Regime Legitimacy: A Comparative Study of Four Latin American Countries. The Journal of Politics, 64 (2), 408-433.

Shih, V. C. (2008a). Factions and Finance in China: Elite Conflict and Inflation. Cambridge, New York: Cambridge University Press.

Shih, V. C. (2008b). Nauseating”’ Displays of Loyalty: Monitoring the Factional Bargain through Ideological Campaigns in China. The Journal of Politics, 70 (4), 1-16.

Shih, V., Adolph, C., \& Liu, M. (2012). Getting Ahead in the Communist Party: Explaining the Advancement of Central Committee Members in China. American Political Science Review, 106 (1), 166-187.

Shirk, S. L. (1993). The Political Logic of Economic Reform in China. Berkeley: University of California Press.

Sun, Y. (2004). Corruption and Market in Contemporary China. Ithaca, N.Y.: Cornell University Press.

Svolik, M. W. (2012). The Politics of Authoritarian Rule. New York: Cambridge University Press.

Taras, R. (1989). Political Competition and Communist Leadership: A Historical Introduction. In R. Taras (Eds), Leadership Change in Communist States. (pp.1-23). Boston: Unwin Hyman.

Teiwes, F. C. (1984). Leadership, Legitimacy, and Conflict in China. Armonk, NY: M.E. Sharpe.

Treisman, D. (2007). What Have We Learned About the Causes of Corruption From Ten Years of Cross-National Empirical Research? Annual Review of Political Science, 10, 211-244. 
Tullock, G. (1987). Autocracy. Dordrecht; Boston: Kluwer Academic Publishers.

Wedeman, A. H. (2004). The Intensification of Corruption in China. The China Quarterly,180(1), 895-921.

Wedeman, A. H. (2005). Anticorruption Campaigns and the Intensification of Corruption in China. Journal of Contemporary China, 14 (42), 93-116.

Wedeman, A. H. (2012). Double Paradox: Rapid Growth and Rising Corruption in China. Ithaca: Cornell University Press.

Welch, S., \& Hibbing, J. R. (1997). The Effects of Charges of Corruption on Voting Behavior in Congressional Elections, 1982-90. The Journal of Politics, 59 (1), 226-239.

Yang, D. L. (2004). Remaking the Chinese Leviathan: Market Transition and the Politics of Governance in China. Stanford, Calif.: Stanford University Press. 